\title{
PENDIDIKAN HUMANIS JOHN DEWEY DALAM PERSPEKTIF PENDIDIKAN ISLAM
}

\author{
Ruma Mubarok \\ Dosen Fakultas Ilmu Tarbiyah dan Keguruan UIN Maulana Malik \\ Ibrahim Malang \\ e-mail: ruma_mubarak@yahoo.com
}

\begin{abstract}
Education is a process toward birth humanization humanly valuable human being. The main agenda of education is the process of humanizing humans being human. That process is called humanization; the human form becomes a true human being. Education as a process carried out by a community in order to prepare the next generation to be able to socialize and adapt to the culture they profess, actually one of the traditions of the human race that is almost as old as mankind. Education had been since time immemorial is one form of human effort in order to maintain the continuity of the existence of life and their culture.
\end{abstract}

Keywords: humanistic education, John Dewey, islamic education.

\begin{abstract}
Abstrak: Pendidikan merupakan proses pemanusiaan menuju lahirnya insan bernilai secara kemanusiaan. Agenda utama pendidikan adalah proses memanusiakan manusia menjadi manusia. Proses itulah yang disebut dengan pemanusiaan, proses membentuk manusia menjadi insan sejati. Pendidikan sebagai proses yang dilakukan oleh suatu masyarakat dalam rangka menyiapkan generasi penerusnya agar dapat bersosialisasi dan beradaptasi dalam budaya yang mereka anut, sesungguhnya merupakan salah satu tradisi umat manusia yang sudah hampir setua usia manusia. Pendidikan memang sudah sejak zaman dahulu kala menjadi salah satu bentuk usaha manusia dalam rangka mempertahankan kelangsungan eksistensi kehidupan maupun budaya mereka.
\end{abstract}

Kata-Kata Kunci: pendidikan humanis, John Dewey, pendidikan Islam. 


\section{Pendahuluan}

Pendidikan sebagai proses yang dilakukan oleh suatu masyarakat dalam rangka menyiapkan generasi penerusnya agar dapat bersosialisasi dan beradaptasi dalam budaya yang mereka anut, sesungguhnya merupakan salah satu tradisi umat manusia yang sudah hampir setua usia manusia. Pendidikan memang sudah sejak zaman dahulu kala menjadi salah satu bentuk usaha manusia dalam rangka mempertahankan kelangsungan eksistensi kehidupan maupun budaya mereka (Wahono, 2000: 2). Dengan kata lain, pendidikan sesungguhnya dapat dikatakan merupakan salah satu bentuk strategi budaya tertua bagi manusia untuk mempertahankan keberlangsungan eksistensi mereka.

Sudarwan Danim mengatakan bahwa pendidikan merupakan proses pemanusiaan menuju lahirnya insan bernilai secara kemanusiaan. Agenda utama pendidikan adalah proses memanusiakan manusia menjadi manusia. Proses itulah yang disebut dengan pemanusiaan, proses membentuk manusia menjadi insan sejati. Dengan kata lain, pemanusiaan adalah proses memanusiakan manusia oleh manusia, sebuah diskursus pendewasaan. Agenda proses pemanusiaan dipandang berhasil manakala dengan itu lahir manusia dewasa sejati, manusia yang sarat dengan tampilan nilai-nilai kemanusiaan.

Namun, bila dilihat di dalam prakteknya, pendidikan tidak lagi murni berusaha untuk mengembangkan potensi-potensi manusia, dalam rangka melaksanakan proses pemanusiaan manusia muda, yakni proses menjadikan seseorang sebagai manusia (homonisasi) dan proses pengembangan kemanusiaan manusia (humanisasi). Bahkan sebaliknya, pendidikan banyak yang cenderung mengarah kepada dehumanisasi (tidak memanusiakan manusia).

Berkaitan dengan gelombang demokrasi kehidupan masyarakat dalam suatu negara biasanya didukung oleh munculnya penghormatan terhadap nilai-nilai kemanusiaan, karena asas demokrasi menjadi penting bagi peningkatan hidup seseorang. Demokratisasi pendidikan mempunyai dampak besar dalam proses perencanaan pendidikan, sehingga pendidikan terarah pada keterbukaan (Tilaar, 1992: 5). 
Dari sini muncul beberapa agenda yang cukup mendesak untuk dilakukan perubahan terhadap struktur dan sistem yang sudah ada. Perubahan struktur fundamental tersebut, menurut Freire, mengandung-sekaligus harus membawa implikasi dinamis dan positif akan makna keadilan dan humanisme. Dikatakan adil karena tidak ada treatment diskriminatif; dikatakan humanis karena tidak ada unsur pemaksaan, tetapi lebih menekankan proses pembebasan, sehingga pendidikan yang benar adalah pendidikan yang direncanakan sebagai proses perubahan, dalam rangka merubah struktur-struktur sosial yang tidak adil menjadi lebih adil dan manusiawi (Maksum, 2004: 110).

Pemikiran semacam ini kiranya saat ini memiliki momentum yang tepat karena dunia pendidikan sedang menghadapi krisis konseptual. Di samping karena begitu cepat terjadinya perubahan sosial yang sulit diprediksi, juga karena intervensi pemikiran nonkependidikan seperti ekonomi dan politik ke dalam pendidikan yang tak dapat dihindarkan. Akibatnya banyak orang tidak puas terhadap sistem pendidikan konvensional dan formal akhirnya mencari solusi lain. Misalnya muncul gagasan "masyarakat tanpa sekolah", "pendidikan tanpa batas", "pendidikan yang membebaskan", dan "pendidikan untuk kaum tertindas".

Dasar pemikiran di atas memunculkan berbagai pertanyaan dan sekaligus tantangan pendidikan ke depan. Dari sini, penulis mencoba mengungkapkan konsep pendidikan humanis John Dewey dalam perspektif pendidikan Islam.

\section{Pendidikan Humanis John Dewey}

\section{Teori Pendidikan}

Apakah pendidikan menurut John Dewey? Pendidikan berarti perkembangan, perkembangan sejak lahir hingga menjelang kematian. Jadi, pendidikan itu juga berarti sebagai kehidupan. Bagi Dewey, "Education is growth, development, life". Ini berarti bahwa proses pendidikan itu tidak mempunyai tujuan di luar dirinya, tetapi terdapat dalam pendidikan itu sendiri. Proses pendidikan juga bersifat kontinyu, merupakan reorganisasi, rekonstruksi, dan pengubahan pengalaman hidup (Maksum, 2004: 110). Dengan demikian, 
pendidikan itu merupakan organisasi pengalaman hidup, pembentukan kembali pengalaman hidup, dan juga perubahan pengalaman hidup sendiri.

Pendidikan merupakan reorganisasi dan rekonstruksi yang konstan dari pengalaman. Pada setiap saat ada tujuan, perbuatan pendidikan selalu ditujukan untuk mencapai tujuan. Setiap fase perkembangan kehidupan, masa kanak-kanak, masa pemuda, dan dewasa, semuanya merupakan fase pendidikan, semua yang dipelajari pada fase-fase tersebut mempunyai arti sebagai pengalaman. Pendidikan itu tidak berakhir, kecuali kalau seseorang sudah mati.

Tujuan pendidikan diarahkan untuk mencapai suatu kehidupan yang demokratis. Demokratis bukan dalam arti politik, melainkan sebagai cara hidup bersama sebagai way of life, pengalaman bersama dan komunikasi bersama. Tujuan pendidikan merupakan usaha agar individu melanjutkan pendidikannya. Tujuan pendidikan terletak pada proses pendidikan itu sendiri, yakni kemampuan dan keharusan individu meneruskan perkembangannya.

John Dewey mengaskan bahwa pendidikan itu tidak mempunyai tujuan, hanya orang tua, guru, dan masyarakat yang mempunyai tujuan. Ia dengan tegas menyatakan "And it is well to remind our selves that education as such has no aims. Only persons, parents, and teacher etc, not an abstract idea like education".

Kapankah proses belajar itu dimulai dan kapankah berakhir? Sesuai dengan pandangan John Dewey, bahwa pendidikan itu adalah pertumbuhan itu sendiri. Karena itu, pendidikan tersebut dimulai sejak lahir dan berakhir pada saat kematian. Demikian juga proses belajar tidak dapat dilepaskan dari proses pendidikan. Pendidikan adalah pengalaman, yaitu suatu proses yang berlangsung terus menerus. Bagaimana hubungan antara proses belajar, pengalaman, dan berpikir?

Pengalaman itu bersifat aktif dan pasif. Pengalaman yang bersifat aktif berarti berusaha, mencoba, dan mengubah, sedangkan pengalaman pasif berarti menerima dan mengikuti saja. Kalau kita mengalami sesuatu maka kita berbuat, sedangkan kalau kita mengikuti sesuatu kita memperoleh akibat atau hasil. Belajar dari pengalaman berarti menghubungakan kemunduran dengan kemajuan dalam perbuatan kita, yakni kita merasakan kesenangan atau penderitaan 
sebagai suatu akibat atau hasil. "To learn from experience is to make a backward and forward connection between what we have do to things and what we enjoy or suffer from thing in consequence".

Dalam penyusunan bahan ajaran, menurut Dewey, hendaknya memperhatikan sayarat-syarat sebagai berikut: 1) Bahan ajaran hendaknya konkret, dipilih yang betul-betul berguna dan dibutuhkan, dipersiapakan secara sistematis dan mendetail, 2) Pengetahuan yang telah diperoleh sebagai hasil belajar, hendaknya ditempatkan dalam kedudukan yang berarti, yang memungkinkan dilaksanakannya kegiatan baru, dan kegiatan yang lebih menyeluruh.

Bahan pelajaran bagi anak tidak bisa semata-mata diambil dari buku pelajaran, yang diklasifikasikan dalam mata-mata pelajaran yang terpisah. Bahan pelajaran harus berisikan kemungkinan-kemungkinan, harus mendorong anak untuk bergiat dan berbuat. Bahan pelajaran harus memberikan rangsangan pada anak-anak untuk bereksperimen. Demikianlah dengan bahan pelajaran ini, kita mengharapkan anakanak yang aktif, anak-anak yang bekerja, anak-anak yang bereksperimen. Bahan pelajaran tidak diberikan dalam disiplindisiplin ilmu yang ketat, tetapi merupakan kegiatan yang berkenaan dengan sesuatu masalah (problem).

2. Hakikat Pendidikan

Pendidikan merupakan proses masyarakat mengenal diri. Dengan perkataan lain, pendidikan adalah proses agar masyarakat menjadi hidup dan dapat melangsungkan aktivitasnya untuk masa depan. Dengan demikian, pendidikan adalah proses pembentukan impulse (perbuatan yang dilakukan atas desakan hati) (Soemanto, 1982: 123).

Pendidikan pragmatisme lebih menekankan pada futuralistik (sebuah pendidikan yang berwawasan masa depan). Karena sifatnya yang future oriented, pragmatisme menolak model pendidikan yang ingin kembali ke masa lampau. Dari karakter yang demikian, maka pendidikan pragmatisme sering disebut sebagai pendidikan modern. Pendidikan modern menganjurkan agar yang berbuat, yang menghasilkan, dan yang mengajar adalah peserta didik sendiri. Sedangkan peran pendidikan lebih berfungsi sebagai fasilitator dan pembimbing (Langgulung, 1985: 28). 
Hakikat pendidikan menurut pragmatisme adalah menyiapkan anak didik dengan membekali seperangkat keahlian dan ketrampilan teknis agar mampu hidup di dunia yang selalu berubah. Pendidikan diyakini mampu merubah kebudayaan baru dan dapat menyelamatkan masa depan manusia yang semakin kompleks dan menantang. Pedidikan adalah lembaga pembinaan manusia untuk survive menyesuaikan diri dengan perubahan cultural dan tantangan zaman (Maksum, 2004: 259).

Konsep pendidikan Dewey yang berlandaskan pada filsafat pragmatisme, menilai suatu pengetahuan dalam masyarakat. Yang diajarkan adalah pengetahuan yang segera dapat dipakai dalam penghidupan masyarakat sehari-hari. Kilpatrik yang dipengaruhi oleh pemikiran Dewey merancang metode pendidikannya yang disebutnya dengan metode proyek. Artinya, anak didik diberi kebebasan untuk menentukan sendiri jenis pekerjaan yang sesuai dengan minatnya, sehingga nanti bisa digunakan dalam kehidupan sehari-hari (Said, 1987: 239).

\section{Tujuan Pendidikan}

Tujuan pendidikan pragmatisme adalah menyiapkan peserta didik menghadapi masa depannya. Untuk mencapai tujuan dimaksud maka perlu ditanamkan disiplin dan membekalinya dengan berbagai keahlian dan ketrampilan, lembaga pendidikan harus mengontrolnya melalui kekuatan eksternal dengan cara membuang semua paksaan, membangkitkan kesadaran diri, melakukan aktivitas untuk mencapai keunggulan tertentu, dan harus mengetahui kecakapan dan minat peserta didik serta menciptakan partisipasi dalam proses belajar (Soemanto, 1982: 124). Dalam pemikiran John Dewey, sekolah memiliki tujuan sosial, artinya tujuan sekolah harus tunduk kepada tujuan itu. Sekolah hendaknya merupakan cerminan dari masyarakat yang bercita-cita demokrasi (Danasaputra, 1985: 88).

4. Tugas Pendidikan

Menurut Dewey, proses pendidikan berdimensi psikologis dan sosiologis. Dimensi psikologis menuntut pendidikan dapat memahami potensi yang dimiliki setiap peserta didik untuk dikembangkan dan mengetahui kemana harus disalurkan. Dimensi sosiologis menuntut pendidikan dapat mengetahui kemana harus dibimbing potensi yang 
dimiliki peserta didik. Dalam pandangan Dewey, potensi yang dimaksudkan harus diabdikan untuk kepentingan sosial, sehingga mempunyai tujuan sosial. Karenanya pendidikan merupakan proses sosial, sedangkan sekolah adalah lembaga sosial (Danasaputra, 1985: 88).

Adapun tugas sekolah adalah sebagai berikut: pertama, sekolah hendaknya dapat menggantikan faktor-faktor pendidikan dalam keluarga (nilai kerjasama, tolong-menolong, dan tanggung jawab hidup). Sekolah hendaknya dapat menjadi fungsi sebagai sekolah kerja. Kedua, sekolah hendaknya mencerminkan masyarakat, yang inti dari pelajaran sekolah berhubungan dengan masyarakat. Peserta didik memasuki lapangan penghidupan yang sesungguhnya dengan pola belajar sambil bekerja. Ketiga, sekolah hendaknya sanggup menyiapkan peserta didik dengan cara melatih untuk memikul tanggung jawab, inisiatif, dan pandangan sosial dalam menghadapi masa depan.

Dalam bukunya Democracy and Education, Dewey menawarkan suatu konsep pendidikan yang adaptif dan progresif bagi perkembangan masa depan. Yakni, pendidikan harus mampu membekali anak didik sesuai dengan kebutuhan yang ada pada lingkungan sosialnya.

Untuk merealisasikan konsepnya tersebut, ia menawarkan dua metode pendekatan dalam pengajaran, yaitu: Pertama, Problem Solving Method. Metode problem solving, anak didik dihadapkan pada berbagai situasi dan masalah-masalah yang menantang, dan anak didik diberi kebebasan sepenuhnya untuk memecahkan problem tersebut sesuai perkembangan kemampuannya. Dalam proses belajar mengajar seperti ini, guru bukan satu-satunya sumber belajar atau ilmu, bahkan kedudukan guru hanya membantu siswa dalam memecahkan kesulitan yang dihadapinya, kedua, Learning by Doing Method. Metode ini sebagai upaya untuk menjembatani kesenjangan antara dunia pendidikan dengan kebutuhan dalam masyarakat. Supaya anak didik bila telah menyelesaikan pendidikannya bisa eksis dalam masyarakat, maka sejak di sekolah perlu dibekali dengan berbagai keahlian praktis, sesuai dengan kebutuhan masyarakat sosialnya (Maksum, 2004: 261). 


\section{Kurikulum Pendidikan}

Pragmatisme memandang bahwa kurikulum yang tepat adalah kurikulum yang mempunyai edukatif. Sementara menurut Dewey, sekolah yang baik adalah sekolah yang memperhatikan dengan sungguh-sungguh jenis belajar dan dapat membantu perkembangan anak didik. Pendidikan pragmatisme menganut sistem pendidikan berdasarkan aktifitas terpusat. Artinya, aktifitas anak didik menjadi sangat penting karena menjadikan pendidikan lebih hidup, terlebih lagi membuat kehidupan itu memberi kebenaran.

Menurut pragmatisme, tidak ada suatu materi pelajaran tertentu yang bersifat universal dalam sistem dan metode pelajaran yang selalu tepat untuk semua jenjang sekolah. Sebab seperti pengalaman, kebutuhan serta minat individu atau masyarakat berbeda menurut tempat dan zaman. Dalam hal ini kurikulum juga bersifat elastis dan fleksibel sesuai dengan tuntutan dan kebutuhan masyarakat. Kurikulum pragmatisme bergerak dinamis di atas prinsip kebebasan. Pragmatisme menghendaki bentuk yang bervariatif dan materi yang kaya dalam kurikulum. Sekalipun demikian pragmatisme tetap memerlukan suatu perencanaan pendidikan dan adanya kurikulum, namun atas prinsip dinamis bukan pola yang statis.

Dalam mengembangkan kurikulum, pragmatisme berpedoman pada lima struktur kurikulum, yaitu: pertama, reorganisasi di dalam subyek khusus pendidikan sebagai langkah pertama mencari pola dan desain baru. Kedua, korelasi dan kedekatan antara dua atau lebih materi pelajaran. Ketiga, pengelompokkan dan hubungan integratif dalam satu bidang pengetahuan. Keempat, "core curriculum", suatu kelompok mata pelajaran yang memberi pengalaman dasar dan sebagai kebutuhan umum yang utama. Kelima, "experience-centered curriculum", yakni kurikulum yang mengutamakan pengalaman dengan menekankan pada unit-unit tertentu.

Dalam pelaksanaannya, kurikulum yang mengutamakan pengalaman didasarkan atas kebutuhan dan minat peserta didik diarahkan bagi perkembangan pribadi secara integral terutama aspek pikir, perasaan, motorik, dan pengalaman sosial. 


\section{Perbedaan Konsep Pendidikan Humanis John Dewey dengan Pendidikan Islam}

Berdasarkan uraian pada bab-bab sebelumnya, ada beberapa aspek yang dapat diperbandingkan antara pendidikan John Dewey dengan konsep pendidikan Islam. Beberapa hal itu ialah:

Pertama, konsep pendidikan yang diuraikan oleh Dewey tersebut tidak ditemui dasar pemikirannya yang menunjukkan dan mengarahkan pada kebenaran Tuhan. Ditinjau dari konsep pendidikan Islam, maka konsep pendidikan Dewey tidak menunjukkan proses pendalaman agama, proses mengenal pencipta manusia, dan proses mengenal dirinya sendiri, melainkan seperti yang dikatakannya bahwa, "it is the very nature of life to strive to continue in being. Since this continance can be secured only by constant renewals, life is a selfrenewingprocess. What nutrition and reproduction are to physiological life, education it is social life". Seolah pendidikan kata Dewey adalah kebutuhan sosial karena solidaritas sosial ini akan memunculkan ketentuan-ketentuan yang dianut oleh masayarakat tersebut (Taufik Abdullah, 1991: 31). Oleh karena itu kalau nutrisi dan reproduksi itu kebutuhan biologis maka seolah sosial adalah kebutuhan ruhaninya. Karena sosial adalah kebutuhan ruhani maka perlu disiapkan melalui pendidikan.

Dari sini tampak bahwa pernyataan Dewey tersebut, tidak menunjukkan dan mengarahkan pada ketentuan Tuhan dan kebenaran-Nya. Tampak bahwa sosial inilah orientasi pendidikannya. Masyarakatlah yang akan membuat ketentuan-ketentuan atau peraturan dalam kehidupan. Dari sini sekaligus menunjukkan bahwa pendidikan menurut Dewey hanya mengarah kepada kehidupan dunia saja. Seolah tidak ada lagi kehidupan sesudah manusia mati.

Dalam pandangan Islam, Konsep pendidikan Islam mempunyai dua orientasi pendidikan, yaitu orientasi kehidupan duniawiyah dan orientsi kehidupan ukhrawiyah. Karena proses pendidikan dalam Islam mengorientasikan manusia untuk mencapai tujuan hidupnya, yaitu bahagia dunia dan akhirat (M. Arifin, 1996: 112).

Kedua, di dalam konsep pendidikan humanis, terdapat suatu orientasi tujuan pendidikan yang bisa dikatakan mulia, yaitu tujuan untuk memanusiakan manusia (proses humanisasi) dengan 
meningkatkan harkat dan martabat manusia sebagai manusia. Untuk mencapai tujuan tersebut dalam konsep ini diperlukan suatu usaha "penyadaran" (konsientisasi) yang harus dipenuhi terlebih dahulu oleh manusia. Dengan penyadaran, manusia akan merasa sungguh-sungguh menjadi manusia, karena kesadaran adalah salah satu ciri dari hakekat manusia itu sendiri, yang bisa membedakan dengan makhluk yang lain.

Oleh karena itu, konsep pendidikan humanis memandang perlunya suatu upaya agar manusia mempunyai kesadaran kritis bukan kesadaran yang naif. Sebagai jalan untuk mencapainya yaitu dengan meletakkan pendidik dan peserta didik pada posisi yang sama, yakni posisi yang sama-sama menjadi subyek (pelaku) pendidikan yang sadar. Keduanya sama-sama diberi kebebasan untuk berfikir kritis dan mengekspresikan aktivitasnya, serta sama-sama mempelajari dan mengkritisi realitas dunia dan pengetahuan sebagai obyek pendidikannya.

Tujuan yang ada dalam pendidikan humanis tersebut, menurut pandangan Islam merupakan sesuatu yang tidak bertentangan dengan ajaran Islam itu sendiri. Karena Islam adalah agama yang menjunjung tinggi nilai-nilai kemanusiaan, dan mengutuk keras bentuk-bentuk kegiatan yang mengarah kepada penindasan, pemaksaan dan perampasan harkat dan martabat manusia. Islam dengan konsep pendidikannya juga bertujuan untuk menjadikan manusia yang benarbenar menjadi manusia (humanisasi) dan dengan pendidikan, Islam meningkatkan martabat dan derajat manusia.

Hal ini juga pernah dipertegas oleh cendikiawan muslim legendaris yaitu Imam Al-Ghazali, bahwasanya menurut beliau proses pendidikan yang bertujuan untuk memanusiakan manusia sejak masa kejadiannya sampai akhir hayatnya melalui ilmu pengetahuan yang diberikan, belum bisa dikatakan mampu menjadikan manusia sempurna, kecuali pendidikannya berorientasi pada pendekatan diri kepada Allah. Untuk itulah Al-Ghazali membagi tujuan pendidikan menjadi dua yaitu jangka pendek dan jangka panjang (Abidin Ibn Rusn, 1998: 56).

Keempat, mengenai pendidik dan anak didik, konsep pendidikan humanis menempatkan keduanya pada posisi yang sama, yaitu samasama menjadi subyek pendidikan. Implikasi lebih lanjut dari 
persamaan "status" tersebut menjadikan keduanya sama-sama aktif di dalam proses pendidikan, sehingga tidak ada lagi istilah pendidik adalah subjek aktif yang dengan otoritasnya mempunyai wewenang dalam mengatur dan mengendalikan anak didik yang dianggap objek yang pasif dan patuh. Maka dari itu, konsep pendidikan humanis menentang keras pendidikan klasikal yang dianggap telah merampas kebebasan anak didik untuk berfikir kritis, berkreasi dan berekspresi dalam proses belajar mengajar, yang akhirnya mengakibatkan anak didik merasa terbelenggu dan tertindas haknya.

Hal tersebut di atas, juga dapat dijumpai dalam konsep Islam. Dalam hal ini Islam tidak pernah membeda-bedakan suatu derajat manusia dari segi kedudukan atau pangkatnya, keturunan maupun kekayaannya, semua sama dihadapan Allah Swt, melainkan yang dapat membedakannya yaitu kualitas ketaqwaan manusia itu sendiri (M. Arifin, 1996: 55). Untuk itu dalam konteks pendidikan Islam juga memandang antara pendidik dan anak didik sebagai subyek pendidikan yang sama-sama aktif di dalam proses transformasi ilmu pengetahuan .

Walaupun ada kesamaan antara pendidikan humanis dengan pendidikan Islam dalam menempatkan posisi guru dan murid sebagai subyek pendidikan, tetapi yang menarik untuk disoroti dari konsep pendidikan humanis di sini adalah bahwasanya posisi anak didik sebagai subyek pendidikan merupakan posisi yang diberikan kebebasan secara mutlak, padahal yang mempunyai kebebasan mutlak hanyalah Allah. Manusia menurut Islam hanyalah mempunyai kebebasan yang sifatnya relatif, yaitu kebebasan yang masih dibatasi oleh kebebasan orang lain.

Untuk itu, kalau dalam pendidikan humanis anak didik yang selalu diarahkan oleh gurunya dan harus patuh dengan apa yang dikatakan atau dinasehatkan kepadanya merupakan sesuatu yang menindas kebebasan kreativitas murid dan membelenggu daya kritisnya. Pandangan seperti itu menurut Islam merupakan pandangan "yang tidak terlalu benar", karena dalam proses pendidikan, kedewasaan seseorang (anak didik) itu adalah sesuatu yang bertahap, sesuai dengan tingkat intelektual dan mental (psikis) anak didik. Sehingga dalam hal-hal tertentu atau masa-masa tertentu anak didik 
memang harus bergantung kepada orang lain dan juga perlu diarahkan baik dari segi pengetahuan maupun segi etika atau moral, dan ini perlu sekali peran aktif seorang pendidik.

Kelima, mengenai metode pendidikan. Sebagaimana yang telah disinggung di atas, bahwasanya pendidikan humanis meletakkan antara pendidik dan anak didik pada posisi yang sama, yakni samasama menjadi subyek pendidikan. Langkah yang lebih praktis lagi dari penempatan posisi yang egalitarian ini, yaitu dengan meletakkan keduanya dalam konteks pendidikan yang dialogis, yang mana menurut pandangan ini (pendidikan humanis) bukan lagi guru berbicara kepada murid, atau guru berbicara untuk murid, tetapi guru berbicara dengan murid.

Metode ini sangat ditekankan dalam praktek pendidikan humanis, karena kebebasan seseorang dalam proses pembelajaran pada hakekatnya terletak pada peran ikut sertanya seorang murid secara aktif dalam mengemukakan pemikirannya dan bersama guru memecahkan suatu permasalahan secara bersama-sama pula. Inilah yang dalam konteks pendidikan humanis dianggap sebagai strategi yang dapat menjadikan anak didik terangsang untuk berfikir kritis sehingga mampu mengkritisi realitas dunia dan pengetahuan yang dipelajarinya.

Bila dilihat dari "teropong" Islam, metode dialog atau pendidikan yang dialogis seperti tersebut, dapat juga dijumpai pada konsep pendidikan dalam Islam, dan merupakan metode pendidikan yang dapat menjadikan ruangan "kelas" menjadi hidup. Metode ini juga dianggap sebagai metode yang dapat meningkatkan pemahaman murid tentang pengetahuan yang dibicarakan di dalam proses pembelajaran (M. Arifin, 1996: 211).

Tetapi kelemahan dari metode dialog dalam konsep pendidikan humanis yang didasarkan atas kebebasan seluas luasnya bagi individu untuk mengemukakan gagasan dan pemikirannya, biasanya akan mengakibatkan suatu tindakan saling salah menyalahkan jika terdapat suatu perbedaaan pendapat antara guru dan murid, sehingga memungkinkan terjadi suatu tindakan yang "anarkis" karena tidak didasari oleh dialog yang akhlaqy, dan ini menurut pandangan Islam tidak diperkenankan sama sekali. Untuk itu seharusnya dialog menurut 
pandangan Islam yang memberikan kebebasan, bukan berarti memberikan kebebasan secara seluas-luasnya atau tanpa batas, tetapi dalam konteks Islam hal tersebut perlu dibatasi dengan adanya sopan santun.

\section{Relevansi Konsep Pendidikan Humanis John Dewey Dengan Pendidikan Islam}

Terlepas dari kekurangan dan kelemahan yang terdapat dalam konsep pendidikan humanis. Dalam hal ini akan mencoba mencari titik temu dari segi kelebihan konsep tersebut. Yang selanjutnya akan dicari relevansinya dengan pendidikan Islam. Ini menarik sekali untuk di pertemukan dengan pendidikan Islam sebab dalam sisi positif gagasangagasan dalam konsep pendidikan humanis memang mempunyai kemiripan dengan Islam yang menjadi dasar pendidikan Islam itu sendiri. Sehingga mempertemukan konsep pendidikan humanis dengan pendidikan Islam akan ditemukan suatu ide-ide baru yang lebih "konstruktif" yang dapat dijadikan pengembangan wacana dalam pendidikan Islam secara praktis.

Ada beberapa hal dari konsep pendidikan humanis yang relevan dengan pendidikan Islam atau Islam secara umum, yaitu:

Pertama, paradigma yang ditekankan oleh konsep pendidikan humanis adalah faktor manusia dan struktur tradisi opresif yang harus dirubah. Manusia dalam pandangannya merupakan subyek dan pelaku sejarah, bukan sebagai obyek yang ada dalam sejarah. Untuk benarbenar menjadi subyek dan pelaku sejarah maka kebebasan sebagai kondisi ontologis yang melekat pada manusia harus dipertahankan. Sehingga ia memiliki kebebasan untuk menentukan pilihan-pilihan artikulasi kesadarannya dalam memaknai kehidupannya. Inilah yang membuat manusia dapat beraksi dan berefleksi, yang membedakan manusia dengan makhluk yang lain (binatang). Hal tersebut juga dapat dijumpai di dalam Islam, di mana Islam dalam konsep pendidikannya menekankan aspek manusia sebagai subyek dalam pendidikan. Islam juga menempatkan manusia sebagai makhluk historis yang berbeda dengan binatang yang a-historis, sebab manusia mempunyai kelebihan dan kesempurnaan yang diberikan oleh Allah kepadanya, sebagaimana yang termuat dalam al-Qur'an surat al-Tiin ayat 4, yang berbunyi: 


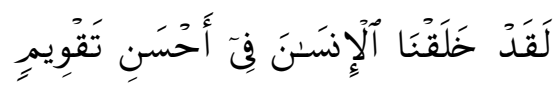

Selain itu Islam juga memaknai kebebasan sebagai fitrah manusia, yakni kehendak bebas sebagai nilai dasar yang harus dijaga dan harus dihormati serta dipertahankan. Implikasi dalam hal ini adalah menuntut seseorang agar menjadi manusia yang aktif dalam pendidikan maupun dalam bekerja, sebab Islam tidak menyukai orang yang hanya pasrah (pasif) dan tidak mau berikhtiar. Padahal dengan tindakan yang aktif baik dengan aksi maupun refleksi, manusia akan menjadi manusia yang sesungguhnya. Allah sendiri tidak akan merubah manusia untuk manjadi manusia yang sebenarnya kalau tidak manusianya sendiri yang merubahnya, sebagaimana yang tergambar dalam al-Qur'an surat ar-Ra'd ayat 11, yang berbunyi:

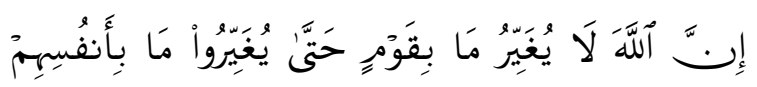

Kedua, dengan paradigma yang ditekankan pada aspek manusia, pendidikan humanis tersebut mempunyai tujuan untuk memanusiakan manusia dan membebaskan manusia dari semua bentuk ketertindasan dan pembelengguan eksistensinya sebagai manusia. Hal ini juga terlihat dalam hakekat tujuan yang terdapat dalam pendidikan Islam, yaitu untuk meningkatkan harkat dan martabat manusia pada tempat yang manusiawi (humanisasi) sehingga menjadi manusia yang sempurna. Pendidikan Islam juga bertujuan untuk membebaskan manusia dari ketertindasan "ke-jahiliyah-an" (kebodohan) dan keterbelakangan dalam segi ilmu pengetahuan, sehingga menjadi orang yang meningkat harkat, martabat dan derajatnya sebagai manusia, baik dalam pandangan manusia maupun pandangan Allah swt. (M. Arifin, 1996: 235).

Ketiga, pandangan pendidikan humanis tentang pendidik dan anak didik sama halnya dengan pendidikan Islam tentang keduanya, yakni menempatkan keduanya pada posisi yang sama yaitu sebagai subyek pendidikan yang dituntut sama-sama aktif dalam proses pembelajaran. Pendidik sebagai orang yang lebih dewasa adalah mempunyai tanggungjawab untuk mengantarkan anak didiknya untuk berpikir kritis dan menjadi manusia dewasa yang mandiri dan bertanggungjawab. Dalam konteks ini tidak ada perendahan martabat 
atau klaim-klaim yang memposisikan pendidik sebagai pihak yang derajatnya tinggi dan lebih punya otoritas "berkuasa" dalam diri anak didik, sedangkan anak didik seakan menjadi pihak, karena menjadi murid yang derajatnya dianggap lebih rendah dan lebih bersifat pasif yang senantiasa diwajibkan untuk "anshituu wasma'uu wa'athi'uu" tanpa ada reaksi (dalam arti positif) yang menjadikan anak didik mempunyai kesadaran kritis. Di sini tidak ada suatu justifikasi yang mengatakan bahwa pendidik (guru) adalah orang yang paling berilmu sehingga dialah simbol orang yang pintar sedangkan anak didik (murid) yang menimba ilmu darinya secara otomatis adalah dibawahnya. Padahal sebenarnya Islam tidak ada klaim-klaim seperti itu, yang ada adalah pembeda orang yang berpendidikan dengan orang yang tidak berpendidikan.

Keempat, mengenai metode pendidikan humanis yang dialogis terlepas dari kekurangan dan kelemahannya memang merupakan model pendidikan yang mampu mengembangkan daya kritis manusia (pendidik maupun anak didik), mengajak para peserta didik tanpa diskriminasi untuk ikut berperan aktif dalam proses pembelajaran. Ini juga dapat ditemui dalam konsep pendidikan Islam, di mana terdapat beberapa metode yang digunakan dalam proses pendidikannya, salah satunya adalah metode dialog, selain metode-metode yang lain seperti ceramah, diskusi, demonstrasi, dan lain-lain (M. Arifin, 1996: 67). Dengan metode dialog inilah yang akan mengarah kepada proses aktif yang kreatif, sehingga murid tidak hanya berada pada proses "penyesuaian diri" dengan lingkungan belajarnya secara pasif, melainkan selalu melakukan "aksi dan reaksi" untuk mencapai tujuan pendidikan. Selain itu dengan dialog akan membangkitkan rasa percaya diri murid pada dirinya sendiri, sehingga ia tidak menjadi pasif dan minder (Fakultas Tarbiyah IAIN Walisongo: 74). Pendidikan Islam tidak menginginkan "umat Islam" (termasuk para murid) mempunyai sikap lemah, malas dan bersedih hati yang tidak mempunyai rasa percaya diri pada dirinya. Karena selain kebebasan untuk memilih dan proses aktif, percaya diri merupakan bagian dari prinsip pendidikan Islam. Islam sendiri juga pernah meng-ibrah-kan metode dialog tersebut dalam al-Qur'an surat al-Baqarah ayat 31 yang berbunyi: 


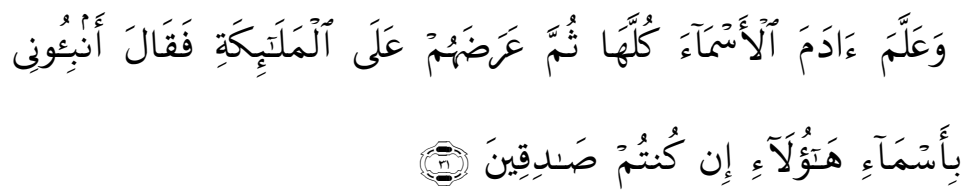

Ayat tersebut menjelaskan tentang terjadinya dialog antara Allah dengan malaikat, Allah dengan manusia dan manusia dengan manusia.

Kelima, konsep pendidikan humanis adalah konsep yang dalam aktualisasinya termuat prinsip kebebasan dan demokrasi. Hal ini sama juga dengan yang ada dalam pendidikan Islam, di mana metode pendidikan dan pengajaran dalam rangka aktualisasi pendidikan Islam sangat banyak sekali dipengaruhi oleh prinsip-prinsip kebebasan dan demokrasi (M. Al-Athiyah Al-Abrasyi, 1970: 5). Secara historis dapat dilihat bahwa praktek pendidikan humanis pernah diterapkan oleh Nabi Muhammad dalam strategi gerakan da'wah Islam menuju transformasi sosial, yang merupakan pembebasan dari eksploitasi, penindasan, dominasi dan ketidakadilan dalam segala aspeknya, khususnya aspek pendidikan. Islam telah menyeruhkan adanya prinsip persamaan dan kebebasan dalam segala segi kehidupan, tidak adanya suatu unsur diskriminasi atas suku, ras, golongan, kedudukan, warna kulit, dan kekayaan, semua dipandang sama-sama mempunyai hak untuk beraktivitas dalam pendidikan. Islam juga tidak mengekang, mengikat atau membelenggu kebebasan setiap individu dalam upaya untuk pengembangan dirinya menjadi manusia yang sempurna. Pendidikan humanis dalam konteks Islam merupakan refleksi dari kemanusiaan manusia yang ditempatkan oleh Islam dalam konfigurasi sistem pendidikan Islam.

Keenam, pendidikan humanis yang dalam konsepnya mengandung tiga paradigma pemikiran pendidikan kontemporer yaitu progresivisme, konstruktivisme dan eksistensialisme sebenarnya bila dikaji lebih dalam ketiganya terdapat dalam dasar-dasar pendidikan Islam. Pendidikan Islam yang bersumber pokok dari al-Qur'an dan Hadits dalam perkembangan zaman memang selalu dituntut untuk senantiasa berkembang sesuai dengan situasi, kondisi dan problematika tuntutan zaman yang memang terus berkembang. Dalam memenuhi dan menjawab persoalan yang ada, maka lahirlah beberapa pengembangan alur pemikiran tentang pendidikan Islam, ada yang 
masih cenderung bersifat konservatif, ada juga yang bersifat doktrinal, normatif dan idealis, bahkan ada juga yang legitimatif-pragmatif. Sehingga muncullah tipologi-tipologi pemikiran filsafat dalam pendidikan Islam oleh para pakar pendidikan Islam (Muhaimin, 2003: 40). Dari alur pemikiran yang legitimatif-pragmatif tersebut, ketiga paradigma yang terdapat dalam konsep pendidikan humanis bisa dibuat "pertimbangan dan perbandingan" untuk dijadikan suatu paradigma baru (bukan secara mutlak) dalam pengembangan pendidikan Islam yang kadang dalam prakteknya masih cenderung normatif-konservatif menjadi paradigma kontemporer yang normatifpragmatif.

\section{Kesimpulan}

Sesuai dengan konsepsi pragmatisme dan progresivisme John Dewey yang telah dijelaskan, ada beberapa perbedaan yang dapat disimpulkan.

Pertama, Manusia sebagai makhluk paling mulia dan sempurna dibandingkan dengan makhluk yang lain, diberikan oleh Allah beberapa potensi yang merupakan fitrah yang melekat pada dirinya. Dengan mengembangkan secara baik beberapa potensi yang fitrah tersebut, manusia akan menjadi wujud manusia yang sebenarbenarnya. Tetapi untuk mengembangkan potensi yang dipunyainya agar dapat mencapai hakekat manusia yang benar-benar manusiawi, maka diperlukan suatu proses pendidikan, sebab dengan pendidikanlah manusia akan mampu mempergunakan potensi yang fitrah tersebut dengan baik. Manusia juga belum bisa sepenuhnya mengembangkan potensi yang dipunyainya kalau tidak dijembatani dengan kebebasan, sebab kebebasan merupakan syarat mutlak untuk mengembangkan potensi tersebut. Untuk itu antara manusia, kebebasan dan pendidikan mempunyai hubungan yang signifikan sekali, karena ketiganya tidak dapat dipisahkan dalam kehidupan ini.

Kedua, Pendidikan humanis merupakan konsep pendidikan yang senantiasa membidik kemanusiaan dan pemanusiaan manusia sebagai tinjauan pokok yang menjadi dasar tujuan untuk membebaskan manusia dari segala bentuk gejala atau praktek pendidikan yang mengarah kepada dehumanisasi. Dengan model pendidikan dialogis, 
pendidikan humanis meletakkan posisi pendidik (guru) dan anak didik (murid) pada posisi yang egalitarian yakni sama-sama sebagai subyek pendidikan yang aktif. Sehingga dengan dialogis itulah akan melahirkan kesadaran kritis yang meletakkan manusia pada posisi kemanusiaannya. Dengan kesadaran kritis itulah manusia (guru maupun murid) akan dapat beraksi dan berefleksi sebagai hasil renungannya mengenai realitas dunia dan pengetahuan secara bebas, sehingga ia mampu bereksistensi dalam kehidupan secara manusiawi.

Ketiga, kedudukan pendidikan menurut progresivisme secara umum, lebih berorientasi pada kehidupan duniawi. Berbeda dengan konsep pendidikan dalam Islam, kedudukan pendidikan dalam Islam adalah suatu sarana untuk mendalami agama, mengenal Allah, dan mengenal dirinya.

Keempat, konsep demokrasi dalam pendidikan lebih dipahami oleh Dewey dengan memberikan materi pendidikan sesuai dengan keinginan anak didik. Hal ini berbeda dengan konsep pendidikan dalam Islam yang lebih mengarahkan anak didik pada tujuan-tujuan keagamaan. Tingkat pemahaman dan pengetahuan anak didik tetap menjadi pertimbangan, namun ada arahan yang jelas untuk mengembangkan anak didik sesuai dengan tujuan-tujuan keagamaan.

Kelima, Bila dianalisa secara mendalam, konsep pendidikan humanis dalam satu sisi terlepas dari kekurangan dan kelemahannya mempunyai relevansi dengan pendidikan Islam atau ajaran Islam itu sendiri. Ada hal-hal tertentu yang bisa dikatakan relevan dengan konsep pendidikan dalam Islam (pendidikan Islam), misalnya mengenai tujuan pendidikan, yang mana antara konsep pendidikan humanis dengan pendidikan Islam sama-sama ingin menjunjung tinggi harkat dan martabat manusia atau memanusiakan manusia, dalam proses pendidikannya juga meletakkan pendidik dan anak didik samasama menjadi subyek pendidikan yang aktif, yang lebih mendasar lagi yaitu bahwasanya pendidikan humanis dalam aktualisasinya termuat prinsip kebebasan dan demokrasi, hal ini sama dengan yang ada dalam pendidikan Islam, di mana metode pendidikan dan pengajaran dalam rangka aktualisasi pendidikan Islam didasarkan atas prinsip-prinsip kebebasan dan demokrasi. 


\section{DAFTAR PUSTAKA}

Rusn, Abidin Ibnu. 1998. Pemikiran Al-Ghazali Tentang Pendidikan. Pustaka Pelajar: Yogyakarta.

Maksum, Ali dan Luluk Yunan Ruhendi. 2004. Paradigma Pendidikan Universal di Era Modern dan Post-Modern. IRCiSoD: Yogyakarta.

Langgulung, Hasan. 1985. Pendidikan dan Peradaban Islam: Suatu Analisa Sosio-Psikologis. Grafindo: Jakarta.

H.A.R. Tilaar. 1992. Manajemen Pendidikan Nasional. PT. Remaja Rosdakarya: Bandung.

Hasbullah. 2003. Dasar-Dasar Ilmu Pendidikan. PT. Raja Grafindo Persada: Jakarta.

I. Jumhur dan Danasaputra. 1985. Sejarah Pendidikan. CV. Ilmu: Bandung.

Barnadib, Imam. 1990. Filsafat Pendidikan, Sistem dan Metode. Yogyakarta: Yasbit FIP IKIP Yogyakarta.

Ismail SM. dan Abdul Mukti (penyunting). 2000. Pendidikan Islam, Demokratisasi dan Masyarakat Madani. Fakultas Tarbiyah IAIN Walisongo Semarang dan Pustaka Pelajar: Yogyakarta.

Dewey, John. 1950. Democracy and Education, An Introduction To The Philosopy of Education. Twenty-Third Printing. USA: The Macmillan Company. 1972. Experience and Education. New York: Collier Books, terj. Haniah. 2004. Pendidikan Berbasis Pengalaman. Cet 1. Teraju: Jakarta. 
Al-Abrasyi, M. Al-Athiyah. 1970. Dasar-dasar Pokok Pendidikan Islam. Bulan Bintang: Jakarta.

Arifin, M. 1996. Ilmu Pendidikan Islam, Suatu Tinjauan Teoritis dan Praktis Berdasarkan Pendekatan Interdisipliner. Bumi Aksara: Jakarta.

Said, Muhammad dan Junimar Affar. 1987. Mendidik dari Zaman ke Zaman. Jemmars: Bandung.

Muhaimin dan Abdul Mujib. 1993. Pemikiran Pendidikan Islam, Kajian Filosofis dan Kerangka Operasionalisasinya. Triganda Karya: Bandung.

. 2003. Wacana Pengembangan Pendidikan Islam. PSAPM Surabaya dan Pustaka Pelajar: Yogyakarta.

Fakih, Mansour dalam Pengantar Francis X. Wahono. 2000. Kapitalisme Pendidikan, Antara Kompetisi dan Keadilan. Pustaka Pelajar Offset: Yogyakarta.

Iman, Muis Sad. 2004. Pendidikan Partisipatif, Menimbang Konsep Fitrah dan Progresivisme John Dewey. Yogyakarta: Safiria Insani Press.

Sukmadinata, Nana Syaodih. 2002. Pengembangan Kurikulum. Bandung: PT. Remaja Rosdakarya.

Abdullah, Taufik. "Agama Sebagai Kekuatan Sosial", dalam Taufik Abdullah dan M. Rusli Karim. Ed. 1991. Metode Penelitian Agama, Sebuah Pengantar. PT. Tiara Wacana: Yogyakarta.

Soemanto, Wasty dan Hendyat Soetopo. 1982. Dasar dan Teori Pendidikan Dunia, Tatangan Bagi Para Pemimpin Pendidikan. Usaha Nasional: Surabaya. 
Ruma Mubarok - Pendidikan Humanis John Dewey dalam Perspektif Pendidikan Islam

Suparlan,Y. B. 1984. Aliran-Aliran Baru Dalam Pendidikan. Yogyakarta: Andi Offset.

Zuhairini, dkk. 1995. Filsafat Pendidikan Islam. Jakarta: Bumi Aksara. 